\title{
KEHIDUPAN KONTEMPORER DALAM WACANA EKSISTENSIALISME MARTIN HEIDEGGER
}

\author{
Oleh: \\ Ahmad Rifai Abun \\ Jamhari \\ Muhammad Hidayaturrohim \\ arifaiabun uin@radenfatah.ac.id, jamhari uin@radenfatah.ac.id, \\ hidayatprilly@gmail.com
}

\begin{abstract}
Contemporary life is coloured with various conveniences. But the convenience is not obtained for free, but must be accompanied by various kinds of problems. Contemporary humans move in a worrying direction and require philosophical reorientation. Through a descriptive analysis approach, this paper explains how to find the format of solutions to contemporary problems through philosophical reorientation with Martin Heidegger's existentialism discourse.
\end{abstract}

Keywords: Contemporary Life, Existentialism, Martin Heidegger

\begin{abstract}
Abstraksi
Kehidupan kontemporer diwarnai dengan berbagai kemudahan. Namun kemudahan itu tidak didapatkan dengan gratis, akan tetapi harus diiringi dengan berbagai macam problematika. Manusia kontemporer bergerak ke arah yang memprihatinkan dan memerlukan reorientasi filosofis. Melalui pendekatan analisis deskriptif, tulisan ini menjelaskan bagaimana menemukan format solutsi masalah kontemporer melalui reorientasi filosofis dengan wacana eksistensialisme Martin Heidegger.
\end{abstract}

Kata Kunci: Kehidupan Kontemporer, Eksistensialisme, Martin Heidegger

\section{A. Pendahuluan}

Filsafat dan kehidupan adalah dua hal yang tidak dapat dipisahkan. Hal ini karena tidak ada peradaban manusia yang dibangun tanpa nilai-nilai filosofis. Filsafat menjadi komponen utama dalam pembangunan paradigma berpikir manusia yang kemudian diwujudkan dalam bentuk budaya dan seterusnya peradaban.

Salah satu tokoh filsafat Barat yang memberi perhatian besar terhadap hakikat keberadaan manusia adalah Martin Heidegger. Hal mana yang membuat ia menjadi tokoh yang berpengaruh dalam kajian eksistensialisme. Bahkan pemikirannya dapat menjadi acuan untuk kehidupan di era kontemporer.

Kehidupan kontemporer selain diwarnai oleh kemudahan akses informasi, juga dipenuhi dengan kebutuhan, keinginan dan rutinitas yang kompleks. Hal ini menyebabkan kehidupan kontemporer berorientasi kepada data-data dan kebenaran objektif dan mengutamakan manusia dengan berbagai keahlian. Di sisi lain, masalah hidup dan masalah kriminal menjadi lebih kompleks sebagai akibat dari meningkatnya kebutuhan. Kondisi ini menyebabkan perlunya reorientasi filosofis dalam rangka mencapai kehjidupan yang ideal di era kontemporer. Tulisan ini mengangkat bagaimana wacana yang diajarkan oleh Martin Heidegger dapat menjadi acuan dalam kehidupan kontemporer. 


\section{B. Karakteristik Kehidupan Kontemporer}

Kontemporer menurut Kamus Besar Bahasa Indonesia diartikan sebagai waktu yang semasa, dewasa ini, atau masa kini. ${ }^{1}$ Karena itu, kehidupan kontemporer berarti ialah suatu kehidupan yang mengandung segala gejala, fenomena, paradigma dan dunia yang sedang berlangsung dan masih terjadi hingga saat ini. Kehidupan di masa kontemporer ini juga tentunya telah memiliki banyak perbedaan yang signifikan dibandingkan dengan kehidupan di masa-masa sebelumnya, beberapa karakteristik kehidupan kontemporer yang ada di masa kini ialah sebagai berikut:

\section{Kemudahan akses informasi}

Berbagai kemajuan di bidang teknologi telah menyebar di masa kontemporer ini. Dimulai dari teknologi mesin yang canggih hingga benda-benda media elektronik, seperti internet, televisi, hingga telepon genggam yang mesti dimiliki oleh setiap orang. Menyebarnya alat-alat canggih ini pun ikut berperan dalam membentuk karakter masyarakat yang baru dan hanya ada di masa kini. Karakter masyarakat kini lebih sering menghabiskan waktu di depan benda-benda elektronik mereka. Berkat alat-alat canggih ini pula berbagai informasi lebih mudah didapatkan

Pada masa kontemporer ini, informasi merupakan bagian dari keseharian masyarakat yang tidak bisa dihindari. Sebab, di dalam kesehariannya terdapat banyak sekali media yang mempublikasikan berbagai informasi kepada khalayak umum. Informasi tersebut pula dapat disaksikan secara langsung melalui media dengan tanpa hambatan, jika dibandingkan dengan zaman-zaman sebelumnya maka tentunya kecepatan memperoleh informasi pada masa kontemporer ini lebih menarik bagi masyarakat. Berbagai informasi yang penting maupun tidak penting pun selalu turut menjadi perhatian dan obrolan bagi masyarakat. Meskipun informasi tersebut merupakan informasi pribadi yang seharusnya tidak layak dipublikasikan.

Banyaknya informasi yang diperoleh pada masa kontemporer ini pula menjadikan masyarakat terlalu sibuk mengurusi informasi kehidupan orang lain yang mereka obrolkan. Bahkan, apabila seseorang tertinggal beberapa informasi saja ia bisa dikucilkan dan dianggap tidak bisa bergaul. Karena itu, bentuk kelompok sosial yang dominan dimiliki oleh masyarakat kontemporer kini ialah berbentuk kelompok sosial yang selalu up to date atau mengetahui kabar informasi terkini. Karena mengurusi informasi kehidupan orang lain itulah yang menjadikan masyarakat masa kini kurang perhatian terhadap pribadinya sendiri, mereka cenderung lebih mencontoh orang yang mereka idolakan di media sosial mereka.

\section{Kebutuhan, keinginan dan rutinitas yang kompleks}

Seiring berkembangnya zaman dan kemajuan teknologi, kini berbagai kebutuhan lebih mudah didapatkan dan lebih beragam, dimulai dari kebutuhan sandang maupun pangan. Berbeda dari zaman-zaman sebelumnya, kebutuhan begitu terbatas dan tidak banyak ragamnya. Oleh karena itu, masyarakat kini lebih memiliki banyak tujuan yang hendak diraihnya dalam kehidupan, dimulai dari memenuhi kebutuhan, kekayaan, status sosial, dan beragam keinginan hasrat yang ingin dipenuhi. Munculnya berbagai kebutuhan sebagai komoditas terpenting dalam pemenuhan kehidupan, turut pula membentuk karakter masyarakat yang materialistis dan konsumeris. 
Karakter masyarakat yang terbentuk karena berbagai kebutuhan ini menjadikan pula masyarakat sibuk untuk memenuhinya. Rutinitas keseharian masyarakat kontemporer kini lebih dimotivasi oleh rasa ingin memenuhi hasrat kebutuhan dan keinginan yang beragam. Motivasi itu timbul karena mereka terlena dalam gemerlap berbagai barang-barang dan hal-hal menarik yang ada di masa kini, meskipun hal tersebut bukanlah termasuk ke dalam kebutuhan sehari-hari mereka. Karena itu pula tidak jarang dari mereka sampai rela menghabiskan seluruh waktunya hanya untuk memenuhi keinginan tersebut. Hal tersebut memang bukanlah perbuatan yang salah, tetapi hal tersebut dapat menjadi penyebab hilangnya arti kehidupan yang mereka jalani.

\section{Berorientasi kepada data-data dan kebenaran objektif}

Pengetahuan sains dan filsafat memang tidak pernah habis dan akan terus berkembang setiap zaman, begitu pula di zaman kontemporer. Pengetahuan pada masa kontemporer kini lebih cenderung kepada data-data statistik yang dapat dikuantifikasi, dan menganggap kurang penting data-data yang bersifat kualitatif. Hal ini disebabkan oleh paradigma pengetahuan yang positivistik dan pragmatik yang berlaku di masa kini. Maka dengan kata lain, zaman kontemporer cenderung menganggap bahwa kemajuan teknologi yang dapat digunakan secara praktis lebih bermanfaat daripada kemajuan berpikir dalam meningkatkan kualitas individu. Karena, teknologi dapat diamati secara objektif dan dapat dirasakan langsung bentuk kegunaannya.

Orientasi yang bersifat objektif ini pula yang membentuk paradigma masyarakat menjadi positivistik. Paradigma tersebut diperoleh melalui pendidikan di sekolah-sekolah dan lingkungan yang menunjukkan akan kemajuan teknologi dan sains. Masyarakat yang kagum akan kemajuan teknologi dan sains perlahan mulai melupakan tradisi lama mereka yang cenderung berorientasi kepada nilai-nilai ajaran spiritual. Meskipun kemajuan teknologi dan sains bernilai sangatlah bagus bagi peradaban, tetapi meninggalkan tradisi nilai-nilai ajaran spiritual merupakan hal yang salah, karena ia mengajarkan tentang moral dan kualitas kehidupan manusia.

\section{Mengutamakan satu keahlian tertentu}

Salah satu karakteristik kehidupan kontemporer yang ada kini adalah selalu mengutamakan keahlian seseorang di bidang tertentu. Berbagai kemajuan di masa kontemporer kini telah membentuk sistem kelompok individu menjadi dua, yaitu kelompok yang ahli dan bukan ahli. Pembagian tersebut tidaklah dibentuk secara sengaja, melainkan ia alami karena paradigma dan orientasi masyarakat kontemporer itu sendiri. Orientasi masyarakat kontemporer yang cenderung positivistik menjadikan disiplin ilmu pun terbagi menjadi beberapa macam, seperti ilmu sosial, hukum, dan sains. Kemajuan di masa kontemporer yang mengutamakan teknologi dan ilmu praktis ini pula telah memaksa masyarakat untuk menjadi ahli di bidang-bidang tertentu guna mendapatkan pekerjaan.

Satu hal yang merugikan dari pembagian keahlian ini ialah apabila seseorang yang tidak ahli di dalam bidang tertentu, atau seseorang yang mengambil gelar dan keahlian bukan di bidang praktis. Maka ia tidak ada pilihan lain selain menjadi seorang yang terbuang dan sulit mendapat pekerjaan. Padahal, masih terdapat banyak potensi dirinya yang bisa digunakan. Tetapi karena ia mengambil gelar dan keahlian yang tidak dibutuhkan di masa kini, maka ia dijustifikasi sebagai orang yang 
tidak ahli. Penjustifikasian ini pula telah membatasi keberadaan manusia itu di dunia. Meskipun pada dasarnya keahlian di bidang tertentu merupakan sesuatu yang sangat penting, tetapi lebih penting lagi apabila seseorang itu dinilai dari totalitasnya.

\section{Masalah hidup dan masalah kriminal yang lebih kompleks}

Tidak bisa dipungkiri bahwa masalah merupakan sesuatu yang selalu hadir di dalam kehidupan. Begitu pula berlaku di masa kontemporer, berbagai kebutuhan dan keinginan yang hendak dicapai oleh setiap orang di masa kontemporer kini bisa membentuk suatu masalah baru yang semakin kompleks. Jika dibandingkan dengan masa-masa sebelumnya, masalah hidup yang dihadapi tidak begitu kompleks karena mereka menjalani hidup dengan apa adanya. Namun, di masa kontemporer yang penuh dengan kemajuan teknologi ini masalah menjadi begitu kompleks. Hidup yang apa adanya itu tidak berlaku lagi di masa kini, berbagai kebutuhan telah mendesak manusia kini untuk mencapai segala pemenuhan kebutuhannya. Dimulai dari kebutuhan sandang pangan yang beragam, kebutuhan listrik, air, bahan bakar kendaraan, hingga kebutuhan telekomunikasi. Padahal selain itu, kebutuhan yang lebih penting adalah peningkatan nilai moral dan kualitas hidup.

Masalah kriminal yang hadir di masa kontemporer kini pun lebih beragam dan kompleks, dimulai dari masalah penyalahgunaan narkoba, penyebaran berita palsu, pencemaran nama baik, penipuan berbasis online, hingga penyalahgunaan wewenang. Karena itulah pendidikan moral dan pengenalan nilai spiritualitas lebih penting untuk mengatasi masalah ini. Namun, karena paradigma positivistik yang berlaku di masa kontemporer kini telah menutup mata masyarakat dari nilai-nilai luhur moral yang seharusnya juga menjadi pedoman hidup bagi manusia.

Beberapa karakteristik kehidupan kontemporer tersebut merupakan beberapa gambaran tentang kehidupan pada masa kini. Karakteristik tersebut mengandung dimensi fisik berupa kemajuan teknologi dan dimensi nonfisik berupa pemikiran dan paradigma masyarakat pada masa kontemporer.

\section{Relevansi Eksistensialisme Martin Heidegger}

Berdasarkan beberapa karakteristik kehidupan kontemporer yang telah dijelaskan sebelumnya, maka dapat ditarik relevansi pemikiran eksistensialisme Martin Heidegger terhadap karakteristik kehidupan kontemporer tersebut, di antaranya ialah sebagai berikut:

1. Eksistensialisme Martin Heidegger sebagai penyaring terhadap informasi di masa kontemporer

Berbagai kemudahan mengakses informasi pada masa kontemoprer ini telah membentuk karakter masyarakat yang pada umumnya selalu membahas informasi terkini. Pembahasan informasi terkini telah menjadi obrolan umum yang terjadi dalam keseharian masyarakat. Terkadang pula masyarakat sering terhanyut dalam obrolan tersebut hingga lupa untuk mengerjakan aktivitasnya. Bahkan, obrolan tersebut dapat pula membawa masyarakat kepada kelupaan akan eksistensinya.

Eksistensialisme Heidegger mampu memberikan peran sebagai penyaring terhadap informasi yang diterima oleh manusia. Obrolan sehari-hari menurut Heidegger disebut sebagai Gerede (obrolan). Obrolan ini membawa Dasein (manusia) berbicara tanpa sadar tentang apa saja mengikuti gerak emosinya yang naik atau turun. Maka dengan obrolan tersebut Dasein mengaburkan diri sebagai 
kemungkinan dan melupakan keterlemparannya. ${ }^{2}$ Melupakan dirinya sebagai kemungkinan untuk menjadi sesuatu merupakan cara manusia untuk menghindari kecemasan yang mesti dihadapinya. Obrolan mengenai informasi terkini tersebut bila dipandang dari perspektif eksistensialisme merupakan salah satu cara manusia untuk menghindari kecemasan yang menghampirinya. Apabila manusia memikirkan kecemasan dirinya, ia akan memikirkan masa depan apa yang akan ia ambil nanti. Memikirkan masa depan tersebut menimbulkan kecemasan hati pada manusia, karena ia harus menghadapi masa depan yang belum diketahui kepastiannya. Maka manusia cenderung lari dari kecemasan tersebut dan mengisi kehidupannya dengan obrolan-obrolan informasi pada masa kini.

Maka salah satu relevansi eksistensialisme Martin Heidegger terhadap kehidupan kontemporer ialah sebagai penyaring terhadap informasi yang ada. Eksistensialisme Martin Heidegger mampu menyaring obrolan sehari-hari yang membuat manusia melupakan keberadaannya, sehingga obrolan tersebut dapat diambil beberapa informasi yang penting saja yang mampu menunjang keberadaannya di masa depan. Bukan hanya mengambil informasi yang tidak bernilai untuk keberadaannya.

2. Eksistensialisme Martin Heidegger sebagai pembatas antara kebutuhan dan keinginan di masa kontemporer

Kebutuhan dan keinginan pada masa kontemporer kini lebih beragam dan menarik perhatian bagi masyarakat. Berbagai barang-barang yang tergolong kebutuhan dan keinginan hampir sulit untuk dibedakan, karena itulah banyak pula masyarakat yang tidak pilih-pilih untuk mengambilnya, terlepas itu untuk mencukupi kebutuhan ataupun keinginan. Banyaknya waktu untuk memenuhi kebutuhan dan keinginan itu menyebabkan masyarakat kontemporer menghabiskan waktunya hanya pada aktivitas bekerja untuk memenuhi kebutuhan dan keinginan tersebut. Eksistensialisme Martin Heidegger menegaskan bahwa kebutuhan yang seharusnya dipenuhi oleh manusia adalah kebutuhan yang memang penting dan berkaitan untuk merancang keberadaannya di masa depan.

Eksistensialisme Martin Heidegger memberikan pembatas antara kebutuhan dan keinginan yang hendak dipenuhi oleh masyarakat kontemporer. Pembatas tersebut dijadikan Heidegger sebagai momen untuk menyusun masa depan yang otentik dan eksis. Menurut Heidegger, masa depan yang otentik disebutnya das Vorlaufen, yang artinya "antisipasi". Maksudnya adalah bahwa Dasein yang menghadapi ada-nya dengan memahami bahwa ia adalah sebuah kemungkinan yang bisa menjadi apa saja, lalu ia mempersiapkan antisipasi untuk menghadapi kecemasan itu untuk keterarahan ke masa depan. ${ }^{3}$ Antisipasi tersebut dapat dilakukan apabila masyarakat kontemporer mau membatasi kebutuhan dan keinginannya. Sebab apabila masyarakat mengambil kebutuhan dan keinginannya secara berlebihan, maka ia sama saja menghabiskan dan menyia-nyiakan waktu. Sedangkan, ia masih memiliki kemungkinan di masa depan yang perlu diperhatikan dan dirancang dari sekarang.

Maka salah satu relevansi eksistensialisme Marin Heidegger terhadap kehidupan kontemporer ialah sebagai pembatas antara kebutuhan dan keinginan yang hendak dipenuhi oleh masyarakat kontemporer. Heidegger memberikan

${ }^{2}$ F. Budi Hardiman, Heidegger dan Mistik Keseharian; Suatu Pengantar menuju Sein und Zeit, Jakarta, Kepustakaan Populer Gramedia, 2008, hlm. 81

${ }^{3}$ Hardiman, Heidegger dan Mistik Keseharian..., hlm. 112 
batasan bagi masyarakat untuk memenuhi kebutuhan dan keinginan sekedar yang penting saja, yaitu kebutuhan dan keinginan yang bisa menunjang keberadaannya di masa depan. Sehingga, masyarakat pula tidak menghabiskan waktunya hanya untuk memenuhi kebutuhan dan keinginan yang tidak penting bagi keberadaan dirinya.

3. Eksistensialisme Martin Heidegger sebagai kritik terhadap dominasi orientasi objektif di masa kontemporer

Orientasi objektif merupakan paradigma masyarakat di masa kontemporer. Segala hal yang berkaitan dengan ilmu pengetahuan dan budaya dikaitkan dengan penilaian objektif semata. Penilaian objektif ini bermula dari paradigma pendidikan yang hanya mengajarkan persoalan-persoalan objektif dan empiris. Hal itu menyebabkan pula paradigma masyarakat hanya mempercayai dan meyakini hal-hal yang mampu diamati secara objektif dan kurang mempercayai hal-hal yang tidak dapat diamati secara objektif. Orientasi objektif semata ini menjadikan masyarakat kontemporer kurang perhatian terhadap penilaian-penilaian yang bersifat subjektif, yang melibatkan rasa empati dan kejiwaan bagi manusia.

Seperti halnya ketika mengamati suatu peristiwa bencana, maka yang akan diambil penilaian dari orientasi objektif adalah sebab-sebab peristiwa bencana itu terjadi secara sains dan logika. Orientasi objektif tidak mengambil pelajaran dari peristiwa tersebut dari sudut pandang subjektif, yaitu pelajaran berharga yang berkesan di hati manusia ketika peristiwa bencana itu terjadi. Oleh sebab orientasi objektif itu pula, masyarakat kontemporer kurang perhatian terhadap eksistensi dirinya yang membahas secara mendalam hingga ke dalam jiwa dan hati dari manusia.

Eksistensialisme Martin Heidegger tidak menolak orientasi objektif tersebut, tetapi ia juga memberikan kritik terhadap dominasi orientasi objektif. Sebab, kehidupan manusia tidak bisa hanya berpaku pada orientasi objektif, melainkan ia juga mesti mendalami orientasi subjektif. Karena dengan orientasi subjektif, masyarakat kontemporer bisa mengambil pelajaran yang berharga dan berkesan bagi eksistensinya ketika menghadapi situasi apapun. Karena bagi Heidegger, Dasein (manusia) terbentuk oleh sesuatu yang mirip "dialog batin", yakni suatu dialog dengan dirinya sendiri karena dia tahu atau selalu dapat tahu bagaimana cara menjadi diri sendiri (artinya, mengetahui kemungkinan-kemungkinan eksistensi yang tersedia bagi diri Dasein). ${ }^{4}$ Dialog batin tersebut tentunya tidak dapat diamati secara objektif belaka, melainkan ia harus diamati secara subjektif. Karena itulah eksistensi manusia bagi Heidegger tidak dapat ditentukan hanya dengan berorientasi objektif, melainkan ia juga harus dipadukan dengan orientasi subjektif agar manusia mampu mengambil pelajaran bermakna dari kehidupannya di dunia.

Maka salah satu relevansi eksistensialisme Martin Heidegger terhadap masa kontemporer ialah sebagai kritik terhadap dominasi orientasi objektif, karena untuk menjadi masyarakat yang eksis tidak semestinya hidup berdasarkan orientasi objektif semata, melainkan ia juga mesti berorientasi subjektif untuk mengarahkan hatinya untuk bertekad dan bereksistensi.

4. Eksistensialisme Martin Heidegger sebagai solusi menghadapi satu keahlian tertentu bagi manusia di masa kontemporer

Keahlian di bidang tertentu telah menjadi kebiasaan umum dalam kehidupan

\footnotetext{
${ }^{4}$ Jean Grondin, Sejarah Hermeneutik dari Plato sampai Gadamer, Jogjakarta, Ar-Ruzz Media, 2016, hlm. 100
} 
kontemporer. Orang-orang yang ahli di bidang tertentu maka sudah ada jalan baginya untuk menuju masa depan yang lebih baik. Sebab, banyak pekerjaan di masa kini yang menuntut calon pekerjanya sebagai ahli di bidang-bidang tertentu. Akan tetapi, tidak sedikit pula terdapat orang-orang yang tidak memiliki keahlian tertentu untuk mendapatkan pekerjaan yang dicarinya. Tidak adanya keahlian ini pula seringkali mendorong seseorang untuk menyerah dan mencari jalan pintas seperti menyogok, maupun mencuri. Karena itu tuntutan akan keahlian di bidang tertentu ini tidak selamanya menjadikan kehidupan lebih baik.

Eksistensialisme Martin Heidegger memberikan solusi untuk menghadapi masa kontemporer yang menuntut akan satu keahlian tertentu ini. Eksistensialisme Heidegger menjelaskan bahwa untuk memahami kehidupan hendaknya ia memahami (Verstehen), serta memperhatikan tiga hal, yaitu Vorhabe, Vorsicht, dan Vorgriff (apa yang sudah dipunyai sebelumnya, apa yang sudah dilihat sebelumnya, apa yang sudah ditangkap sebelumnya), ketiga hal tersebut memberi gambaran bahwa memahami merupakan pandangan untuk menghadapi kemungkinan yang akan datang. ${ }^{5}$ Maksudnya, untuk menghadapi tantangan di masa kontemporer ini manusia harus memperhatikan terlebih dahulu apa yang telah dimilikinya, seperti uang modal, hubungan, ataupun bakat di bidang tertentu. Kemudian ia juga harus memperhatikan apa yang sudah dilihatnya, seperti fenomena, wawasan, maupun pedoman hidup. Serta, ia juga harus memperhatikan apa yang telah ditangkapnya, yaitu berupa pengalaman dan pengetahuan. Maka setelah memperhatikan tiga hal tersebut, manusia telah memahami dirinya bahwa ia bisa menjadi apa saja dan memiliki kemungkinan yang tidak terbatas.

Maka salah satu relevansi eksistensialisme Martin Heidegger pada kehidupan kontemporer ini ialah sebagai solusi untuk menghadapi tuntutan masa kontemporer yang menginginkan satu keahlian tertentu. Solusi tersebut didapatkan oleh manusia ketika ia memahami bahwa dirinya bisa menjadi apa saja di dunia dan tidak bisa terbatasi oleh keahlian tertentu. Teutama apabila ia tidak memiliki keahlian yang diinginkan oleh perusahaan tertentu, ia tidak semestinya berhenti untuk maju. Melainkan, ia mesti memahami potensi dirinya yang bisa menjadi apa saja.

5. Eksistensialisme Martin Heidegger sebagai solusi terhadap masalah hidup dan masalah kriminal yang kompleks di masa kontemporer

Banyaknya masalah yang dihadapi pada masa kontemporer ini disebabkan karena banyaknya kebutuhan hidup yang hendak dipenuhi. Oleh karena itu, untuk menghadapi masalah hidup tersebut tidak seharusnya dihadapi dengan cara yang tidak bermoral. Namun, seiring kehidupan terjalani, pasti terdapat masalah yang menghampiri, dimulai dari masalah ekonomi, sosial, maupun masalah spiritual. Masalah yang semakin kompleks ini terus bertambah seiring kemajuan zaman. Hal yang dikhawatirkan karena banyaknya masalah ini adalah timbulnya masalah kriminal di masyarakat. Tidak dapat dipungkiri bahwa masalah dan kasus kriminal terjadi karena sebab masalah yang dihadapi oleh manusia. Masalah tersebut menjadikannya melanggar aturan-aturan moral dan membahayakan orang lain.

Eksistensialisme Martin Heidegger memberikan solusi terhadap mengatasi masalah yang dihadapi masyarakat kontemporer. Masalah yang dihadapi tersebut merupakan masalah eksistensial yang mempengaruhi manusia, atau dengan kata lain yang bermasalah adalah manusia itu sendiri. Ketidakmampuannya menghadapi

\footnotetext{
${ }^{5}$ W. Poespoprodjo, Interpretasi, Bandung, Remadja Karya, 1987, hlm. 83. Lihat juga F. Budi Hardiman, Seni Memahami; Hermeneutik dari Schleiermacher sampai Derrida, Yogyakarta, PT Kanisius, 2015, hlm. 123
} 
masalah hidup menjadikannya lepas kendali dan menghalalkan segala cara. Maka untuk mengatasinya Heidegger membagi perlakuan dan sikap terhadap masingmasing yang eksis. Untuk menghadapi benda-benda yang berupa alat, maka harus bersikap menggunakannya, mengurusnya (besorgen). Lalu untuk menghadapi benda-benda mati yang bukan alat, maka harus bersikap baisa saja dan tidak merusaknya. Kemudian untuk menghadapi orang lain, Heidegger menegaskan harus bersikap perhatian (fursorgen). ${ }^{6}$ Maka, masalah moral tidak akan terjadi apabila manusia mampu bersikap perhatian dan tidak memanfaatkan orang lain sebagai alat. Karena orang lain bukanlah alat-alat yang bisa digunakan, orang lain memiliki cara berada yang berbeda dengan benda-benda mati. Penghormatan dan perhatian sikap terhadap orang lain ini sebagai landasan moral yang berlaku menurut eksistensialisme Martin Heidegger.

Maka, melalui beberapa relevansi di atas, eksistensialisme Martin Heidegger sangatlah relevan terhadap kehidupan kotemporer. Eksistensialisme Martin Heidegger mengajarkan cara hidup yang baru untuk menghadapi berbagai tantangan di masa kontemporer. Sehingga dengan cara hidup yang baru tersebut manusia bisa memaksimalkan potensi dirinya baik secara fisik dan mental untuk membentuk karakter yang lebih baik. Atau dengan kata lain, manusia yang eksis dan otentik. Apabila cara hidup yang otentik ini selalu diterapkan, maka manusia mampu untuk terus melangkah maju menghadapi masalah di masa yang akan datang, serta tidak melupakan nilai-nilai yang penuh makna yang dijalani dalam kehidupan.

\section{Penutup}

Problematika kehidupan di era kontemporer tak pelak membutuhkan solusi ideal. Wacana filsafat yang diusung oleh Martin Heidegger dapat dijadikan penyaring informasi di masa kontemporer sekaligus pembatas antara kebutuhan dan keinginan di masa kontemporer.

Di sisi lain, eksistensialisme Martin Heidegger juga dapat dijadikan sebagai kritik dan solusi terhadap berbagai masalah. Misalnya sebagai kritik terhadap dominasi orientasi objektif di masa kontemporer dan sebagai solusi menghadapi satu keahlian tertentu bagi manusia di masa kontemporer dan solusi terhadap masalah hidup dan masalah kriminal yang kompleks di masa kontemporer. 


\section{DAFTAR PUSTAKA}

Grondin, Jean, Sejarah Hermeneutik dari Plato sampai Gadamer, Jogjakarta, Ar-Ruzz Media, 2016.

Hardiman, F. Budi, Heidegger dan Mistik Keseharian; Suatu Pengantar Menuju Sein und Zeit, Jakarta, Kepustakaan Populer Gramedia, 2008.

, Seni Memahami; Hermeneutik dari Schleiermacher sampai Derrida, Yogyakarta, PT Kanisius, 2015.

Poespoprodjo, W, Interpretasi, Bandung, Remadja Karya, 1987.

Rahman, Masykur Arif, Buku Pintar Sejarah Filsafat Barat, Yogyakarta, IRCiSoD, 2013. 